\title{
Ubuntu as a spirituality of liberation for black theology of liberation
}

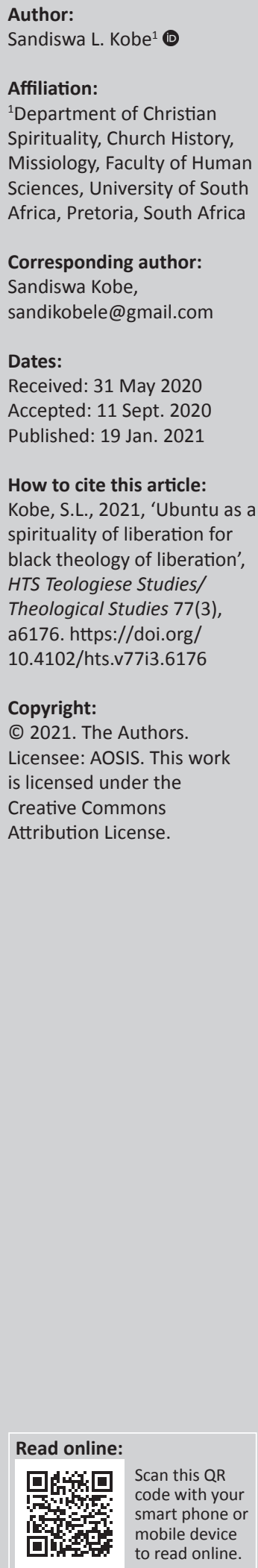

This article aims to respond to Vuyani Vellem's challenge to black theology of liberation (BTL) to 'think beyond rethinking and repeating its tried and tested ways of responding to black pain caused by racism and colonialism'. Vellem argued that 'BTL needs to unthink the west by focusing on and retaining African spirituality as a cognitive spirituality' for the liberation of black people in South Africa. This article argues that Ubuntu is the spirituality of liberation that BTL needs to advance as one of its interlocutors. This research work will consult the literature emerging from African philosophy, ethics, spirituality and BTL arguing that Ubuntu is an indigenous philosophy, spirituality that continues to exist in the languages and culture of the Abantu (Bantu) speaking people. This article is dedicated to the memory of Vellem as a BTL scholar and a faithful believer of the liberative paradigms of BTL.

Contribution: The scholarly contribution of this article is its focus on the systematic and practical reflection, within a paradigm in which the intersection of religious studies, social sciences and humanities generate an interdisciplinary contested discourse.

Keywords: black; liberation; theology; spirituality; Ubuntu; philosophy; Isintu; Abantu.

\section{Introduction}

This article seeks to celebrate the academic contributions made by professor Vuyani Vellem, particularly his work in black theology of liberation (BTL) in South Africa and consequently Africa. In his remembrance, I want to argue that Vellem's BTL has always been ahead of time as he once explained to us that memory is one of the most dangerous phenomena found in South Africa's post-1994.

Vellem once pointed out to us that Voortrekker Monument and Freedom Park symbolises two cultures in conflict with one another in the democratic dispensation of South Africa. He maintained that the precarious rupture of the liberation movements and the formation of new political movements such as Congress of the People (COPE) signalled ambiguity that has prevailed since the dawn of democracy (Vellem 2012). Vellem argued that the loss of the poor as interlocutor for political education in South Africa was a sign of a country descending into chaos because of economic liberation. In the same publication, in which he argued the latter, the African National Congress (ANC) youth league leader Julius Malema broke away from the ANC to form the Economic Freedom Fighters (EFF). In the same year, the Marikana mineworkers were massacred by the ANC government for merely demanding a wage increase from the Lonmin platinum mine in 2012.

Whilst the black urban spaces were characterised by service delivery protests, housing, jobs, evictions, sanitary and other things, these struggles were addressed through protest movements such as Abahlali baseMojondolo and other demonstrations in the townships. ${ }^{1}$ Of course, in 2008, in the same black urban areas, there were attacks on Africans by black South Africans for job opportunities as black South Africans argued that those who own the economy seek for cheap labour from their brothers and sisters who seek refuge in South Africa. Without going into details, it is sufficient to point out that these attacks have been described as 'xenophobia' or 'Afro-phobia' as they are mainly directed at African immigrants. Ngcamu and Mantzaris (2019:1) asserted that research studies indicate that the attacks on African immigrants are always connected to labour disputes over the employment of immigrants, including human traffic, drugs and other things.

1.See http://abahlali.org/taxonomy/term/evictions/evictions/

Note: Special Collection entitled VukaniBantuTsohangBatho - Spirituality of Black Liberation, sub-edited by Fundiswa Kobo (UNISA) and Rothney Tshaka (UNISA). 
Nevertheless, it was in the given context that Vellem (2012:1) argued that no matter how much democratic South Africa seeks to suppress the memory of the poor, the cognisance of the poor remains dangerous. It was not long after that, in 2015, South Africa's democratic dispensation experienced the irruption of this memory as black students formed collective resistance against the status quo. Students formed a coalition that goes beyond political affiliation, arguing for the removal of Cecil John Rhodes (Rhodes) Statue at the University of Cape Town (UCT). The Rhodes Must Fall (RMF) movement argued that Rhodes represented a precarious memory for the black South African in the democratic dispensation.

Like Vuyani Vellem arguing that Voortrekker Monument and Freedom Park symbolises two cultures in conflict with one another, the students argued that Rhodes statue at UCT symbolised white power, racism and a country refusing to transform (Booysen 2016). Therefore, RMF with its Fees Must Fall, End outsourcing and the call for decolonisation of education in South Africa symbolises the suppressed memory of the poor that Vellem (2012) foretold in his article 'Interlocution and Black theology of liberation in the 21st century: A reflection'. Engaging in the student Fallist discourse, Andile Mngxitama stated that 'white racism forced the so-called 'born free' in democratic South Africa 'to see themselves as part of the great black excluded'. The new generation realised that their proximity to whiteness made them assets to the 'white supremacist culture'. ${ }^{2}$

Similarly to their ancestors in the Black Consciousness Movement (BCM), Pan Africanist and Black Power Movements, Fallist movements in South Africa began a process of self-discovery in a society entranced in coloniality and erasure of black people history and culture. ${ }^{3}$ The Fallists envisioned a collective purpose for the progress of the suffering black people in South Africa post-1994, which is economic freedom, land, gender justice and other things.

Responding to Fallist movements in South Africa, Vellem (2015) argued that BTL should not seek to reinterpret, rethink and repeat BTL's tried and tested ways of responding to black pain caused by white racism and colonialism (p. 1). The response of BTL must expand the contours of the Christian faith in African indigenous churches (AICs). More importantly, BTL must embrace other sources for the liberation of the poor outside the confines of orthodox Christian tools. Black theology of liberation must take seriously African spirituality as a cognitive spirituality to liberate Africans from the dungeons of Christianity in Africa. This article, therefore in memory of professor Vuyani Vellem's legacy in BTL, seeks to argue that Ubuntu is the spirituality of liberation that BTL should embrace as interlocutor.

2.Instead of becoming the trusted go-betweens between black people and white people, we are turning to conceptions of blackness and mobilising anger at the very
concept of the Rainbow Nation. The fantasy of a 'colour-blind', 'post-race' South Africa has been projected onto us Coconuts, but our lived experiences are far from free of racism (Chigumadzi 2016).

3.Fallism movements in South Africa include \#Rhodes Must Fall, \#Fees Must Fall, 3.Fallism movements in South Africa include \#Rhodes Must Fall, \#Fees Must Fall \#EndOutsourcing, the service delivery protests (Abahlali baseMojondolo and
others), the Marikana mineworkers, the coming of Julius Malema and the Economic Freedom Fighters (EFF), gender-based violence movements and others.

\section{Christian spirituality in Africa}

According to Vellem (2014:1), it is general knowledge in the BTL school of thought that Western Christianity, accompanied by capitalism in Africa, continues to seek the destruction of indigenous African spiritualities. Against indigenous spiritualities, culture and traditions, Western Christianity presents itself as an official religion declaring its salvation as founded on a truthful belief system.

Vellem (2017) argues that BTL is aware that Euro/Western Christianity is a religion in Africa that continues to expand with modernity whilst proceeding to enforce terror as the experience for Africans (p. 2). In charismatic Pentecostal churches in Africa, we have witnessed black people accepting eating grass, being sprayed with doom at church because they believed that their suffering must be because of condemnation from God. Therefore, they think that the priest will lead them out of their misery and pain, not knowing that the tools applied as salvationist tools in their churches are tools usually seeking their destruction and not their liberation. Unconscious of Steve (Biko1978) argument that:

$[I] \mathrm{n}$ its introduction, Christianity was corrupted by the inclusion of aspects which made it the ideal religion for the colonisation of people. Thus, in its interpretation became the ideal religion for the maintenance of the subjugation of black people. (p. 57)

The people at church are usually ignorant of the fact that Christianity is a religion that is in line with the historic disruption of the moral-ethical dispensation of life amongst the Africans. Their expansion and belief in Western Christianity seek to destroy African civilisation to synchronising it with ascending capitalism (Vellem 2014). Moreover, the people are unwitting of the fact that slaves in the colonies and the indigenous people had only one right, 'to accept Christianity or die' (Ramose 2009:18), and oblivious of the fact that the scramble for Africa in the 19th century took place in the atmosphere of Christian revival. In decolonial discourses, it is argued that:

[K]ey historical events that would explain the European superiority can be traced back to the Italian Renaissance, the Protestant Reformation and the German Aufklarung, and culminate with the French revolution and, in the political sphere, the English Parliament. (Dussel \& Ibarra-Colado 2006:494)

\section{White theologians' sympathy to black theology of liberation in South Africa}

Furthermore, my own experience of church is that black people in the church are uncritical of white theologies' continuity to offer their ancestors spiritualities as the only objective theologies that Africa must adopt in church doctrines and theological education. For example, there has never been a time for African Protestant churches to ask themselves, what is it that they are protesting as Protestant churches in Africa. 
Today, the same Western Christian theology that was used to colonise Africa continues to exist under the disguise of new forms of theological education. Theologies such as public theology, prophetic theology, urban theology and others are purported as theologies addressing black struggles in the black urban areas. Vellem (2017:4) states that Klippies Kritzinger repeated his thesis that he wrote three decades ago in a Sharpeville commemoration in 2016. Vellem (2017) argues that responding to the Fallist call for decolonisation of education, Kritzinger repeated his thesis arguments that the response to black resistance must be in three ways, rejection, sympathy and solidarity with BTL (p. 4).

Vellem argues that in his thesis on theological education, Kritzinger stated that BTL is a foreign theology because it was exported from Latin America, and it encourages 'black racism'. Moreover, Vellem (2017) argues that Kritzinger claimed that BTL is a socialist theology. Therefore, it must be rejected because the 'starting point for black theology is the black people' (Vellem 2017:4). The social analysis of the context of the condition of blackness is fundamental. Again, Vellem (2017:5) argues that Kritzinger speaks about sympathy for BTL. The sympathy is that BTL theologians have rejected because of its 'vexatious expressions of the supremacy and superiority of white responses' to BTL (Vellem 2017:4). Vellem argues that Kritzinger's view of sympathy is the most dangerous because it is sympathy without empathy. It is one that attempts to tell black people what is right and wrong for them, thus seeking to write about black people's pain on their behalf. Vellem (2017) argues that theology is devoid of empathy but has sympathy at its centre that neglects to listen to BTL (p. 5), and I might dare say that it suffers from the white messianic syndrome, the need for white people's views on black pain and liberation to be priorities.

Moreover, Vellem (2017:6) argues that the new theologies that are created use the BTL liberative paradigms. Vellem explains that according to Kritzinger, there must be solidarity with BTL in academic discourses. However, this solidarity with BTL must not think, nor theologise for the sake of the suffering black people. Blackness as an interlocutor must disappear in the creation of these new theologies, and this is why today we have so-called theologies such as public theology, urban theology and prophetic theology. It might be right to add that white theologian presents these theologies in very sophisticated ways continuing to use western methods of theologising as the only academic methods.

Vellem (2017:5) argues what makes white theologians think this way is that although they try by all means to move away from white supremacy, faith betrays white theologians because racism is spiritual. He argues that to think in a racist's manner is not only a cognitive challenge but also a spiritual one because one has to believe that they are utterly superior beings. It is the spirituality of racism that allows white people to suppress guilt 'as beneficiaries of the system that kept black people as underdogs' (Vellem 2017:5).

\section{Is there need to 'Unshackling the church' from its colonial spirituality?}

Within the context of the church, Vuyani Vellem argues that BTL must distinguish between three models of the church in South Africa. There is the settler model of the church that was established by colonists and colonialist who settled in our land to serve the settler community's needs and interests. $\mathrm{He}$ argues that the settler church will always have the interest of the settler economy, discourses as the Dutch Reformed Church supported the apartheid government and provided state theology (Vellem 2015:3).

The second model is the missionary church that established itself within African communities. This church is the one about which Steve Biko argues that it brought with itself a Christian culture that was rigid. Christianity could not adapt to indigenous culture and ways of knowing God. Africans had to change their clothing, their customs, medical approaches, armaments, etiquette and those who remained in the old ways of being were treated with contempt and suspicion. Thereby, in these missionary churches in African communities, Africans were divided into two: the converted (Amaqgobhoka) and the unconverted (Amaqaba). Biko argues that these two groups became the playground for the colonialist as the new Christian religion alienated Africans from each other.

The missionary church, of course, has provided education to the very first so-called coconuts like Tiyo Soga, who then used the same platform to encourage the revolutionary culture in South Africa. However, although this is true, the missionary church remains a hazardous model of the church in Africa because the missionary church comes within Western Christianity that seeks to conquer and colonise the African self.

The adaptation of BTLs liberative paradigms in missionary churches in African communities is performed and enacted within the superiority and inferiority complex syndrome. The adoption of BTL's liberative heritage in the church is assimilated to western ways of being church. After sometimes, the meaning of BTL's liberative paradigms is lost, as the church seeks to fit their theologies to the Euro/West founders of the churches. To illustrate this, as the very first black minister and black theologian Tiyo Soga wrote many songs that include Lizalis'dinga lakho that lamented the black situation in the frontier wars. However, his songs in these mainline churches that were to serve black spirituality in the church were sanitised to fit the missionary gospel of conversion and civilisation.

Nevertheless, Vellem (2015) argues that from the perspective of a BTL, the settler, missionary models of churches remain a 
'dangerous memory' for black people, as their spirituality is a pervasive one that is still dominant today despite attempts to deal with it. Today, the mainline churches in South Africa are struggling with their identity even with black people at the management positions of these churches.

For example, the Methodist church that I attend as a lay preacher is still preaching against African spirituality. I, in fact, had a supervisor who argued that only one spirituality exists, that is Christian spirituality and everything else including African spirituality should be treated with superstition. The question to be asked here is if Methodists can love and worship the teachings of their ancestor John Wesley and still argue or believe to be Pan Africanist?

Nonetheless, perhaps it is enough to argue that black spirituality, thus African spirituality, is trapped within colonial roots of spirituality within mainline churches and can only be relevant if they disentangle themselves from colonial sources and the foundations of systematic oppression. The settler, missionary churches remain an instrument of cultural domination by those who perpetuate the hegemony of ecclesiological insights and theologies that present their Euro/Western spirituality and culture as normative in the interpretation of the gospel of Jesus.

To summarise, the settler-colonial church within the context of ecumenism has had lasting dangerous effects on oppressed black people in South Africa. In South Africa's transitional period from the apartheid to democratic South Africa, the church facilitated the negotiations through the leadership of Tutu (1990) that was recorded in the Rustenburg Declaration (Rotblat 2001).

However, I want to argue that the most remarkable example of the lasting effects of the settler-colonial church was witnessed at the Truth and Reconciliation Commission (TRC) of South Africa. At the TRC proceedings, Tutu used his powerful position as the Archbishop of the Anglican church and a religious figure to influence black South Africans to offer forgiveness to perpetrators of gross human right violations without any form of justice. Tutu used his pastoral experience to induce acts of reconciliation telling black South Africans that Jesus calls them to reconcile with wrongdoers, without demanding justice for victims. Moreover, he described personal moments of forgiveness at the TRC as inspired by the spirit of Ubuntu, and he argued that the compelling force behind the desire to find forgiveness in the painful, impossible moments was made possible by the spirit of Ubuntu (Tutu 1999). According to Tutu (1999:31), what constrained black South Africans at the TRC to choose forgiveness and to be generously forgiving than seeking revenge and making demands for retribution was an indication of the spirit of Ubuntu. Allan Boesak, as one of the proponents of BTL, found the articulation of forgiveness as Ubuntu from Tutu disturbing, if not disgusting. Against Tutu's assertions of forgiveness, Boesak (2017:120) argued that then if Ubuntu is victim of land conquest, colonialism and apartheid abandoning their right to make demands for justice for gross human right violations, Ubuntu, therefore, must be violent towards Ubuntu itself; it is an Ubuntu that needs Ubuntu.

Boesak argued that it is interesting that Tutu used the word forgiveness and twice juxtapose it with revenge and retribution when he describes Ubuntu. Boesak argues that first Tutu (2017) speaks about people who 'choose' and 'are ready to forgive' and thus 'to forego their right to demand the satisfaction of retribution' (p. 119). He argues that it is interesting that these people are ready to let go of their rights of the basic human instinct to demand the right to justice given by law.

Responding to his examination of Tutu's work, Boesak (2017:119) argues that we must recognise that Tutu's Ubuntu is a Christianised Ubuntu. Analysing Tutu's notion of Ubuntu, Boesak argues that it resonates with the Christian gospel, as Tutu (2017) argues that Ubuntu is hospitable and compassionate. It is important to know that 'I am a person through other persons: I am because I am human, open and available to others, affirming of others' (p. 121). Boesak quotes Tutu: 'Ubuntu gives people resilience, enabling them to survive and emerge still human despite all efforts to dehumanise them' (Boesak 2017:31). Boesak points out that when Tutu describes Ubuntu in the ways mentioned above, he received nods around the world. However, if Ubuntu encourages victims, oppressed people to abandon the need for justice is that still Ubuntu or is it 'Matthew 18:22, where we are instructed to forgive not seven, but 77 times ...' (Boesak 2017:119). Against this, therefore, without describing how Boesak describes Ubuntu himself, Boesak argues that Tutu's presentation of Ubuntu is violent towards Ubuntu itself. Boesak (2017) explains that if forgiveness at proceedings of the TRC is Ubuntu and what Tutu describes as Ubuntu is Ubuntu; then, Ubuntu is in desperate need of Ubuntu (p. 122).

In conclusion, Biko's argument that the black people church within the settler, missionary church model is poisonous remains true, and our people are condemned into worshipping them as they try to find meaning for their suffering and pain in a church that offers no liberation (Biko 1978). It is, therefore, from this background that Vellem argues that BTL must align itself with African spirituality and advance African spirituality as a cognitive spirituality, culture for the liberation of black people (Vellem 2014).

\section{African spirituality as the cognitive spirituality' for the liberation of black people}

In a literal sense, I want to argue that Boesak is right to voice out that Ubuntu is in imperative need of Ubuntu. Ndumiso Dladla articulates this idea of 'Ubuntu in desperate need of Ubuntu' very well in his article titled 'Towards an African critical philosophy of race: Ubuntu as a Philo-praxis of 
liberation', published in 2017. Dladla (2017:43) laments the fact that since 1994, there has been enormous interest in Ubuntu in academic and public discourses, but this has been without Abantu (the Bantu people in which Ubuntu emanates from) and Isintu (the culture in which the philosophy of Ubuntu is based).

Dladla (2017:43) argues that the tremendous work on Ubuntu post-1994 has been without Abantu (the Bantu speaking people whose philosophy it is). More importantly, it is Ubuntu developed without Isintu (the culture which is the basis for the philosophy of Ubuntu). Dladla contends that Ubuntu that came after 1994 continues to employ and sustain the epistemologies initiated at the conquest of the indigenous people of South Africa in the unjust land wars of colonisation. Here, I want to add that it is from this background that Ubuntu needs to untangle itself from the colonial project of post-1994 that advances Western Christian spirituality through Ubuntu. To stop perpetuating the spirituality of racism, Ubuntu must be studied outside Christianity, so that Ubuntu can manifest itself as it continues to exist in the language, culture and spirituality of the Bantu speaking people. So, therefore, as Vellem has argued before, BTL must expand contours of Christian faith outside of Christianity and thus seek other sources for the liberation of poor outside the confines of orthodox Christian tools (Vellem 2017).

Therefore, the following section explores Ubuntu and reconceptualises it outside Christianity and western epistemologies as Vellem has challenged BTL. Thus, in what follows this article links Ubuntu to African spirituality, religions and culture.

\section{Ubuntu as a philosophy liberation}

From the perspective of the philosophy of liberation, Mogobe Ramose argues that Ubuntu is the philosophical foundation of African philosophy amongst the Bantu people. Ubuntu is the fundamental, ontological and epistemological category in the thought of the Bantu people. For instance, he points out that 'Ubu' always orients towards 'Ntu' at the ontological level and there is no strict and literal separation and division between 'Ubu' and 'Ntu' in Ubuntu. Moreover, he argues that 'Ubu' and 'Ntu' are not radically separated and irreconcilably opposed realities. 'On the contrary, they are mutually founding in the sense that they are two aspects of "be-ing" as a one-ness and an indivisible whole-ness' (Ramose 2009:36). Ramose explains that although 'Ubu-' as the generalised understanding of be-ing may be said to be distinctly ontological, 'Ntu' is a nodal point in which being assumes concrete form or mode of being in the process of continual unfoldment, which may be said to be distinctly epistemological (Ramose 2009:36).

Accordingly, Ramose (2009) and Dladla (2017) argue that Ubuntu is always a -ness and never an -ism and this is because the logic of Ubu-being the recognition that motion is the principle of be-ing. It is the understanding of be-ing as a verbal and continual motion that is always in the constant state of revision and reconfiguration making the translation of Ubuntu into Human-ism untenable.

Dladla argues that in philosophical terms, uMuntu that is found in uMuntu nguMuntu ngaBantu precedes Ubuntu ontologically and by virtue of such precedence, uMuntu is the progenitor of the epistemology of Ubuntu. Although Dladla warns that English is inadequate in proving the exact meaning of uMuntu nguMuntu ngaBantu, he points out that Ramose's translation of the aphorism 'to be a human be-ing is to affirm one's humanity by recognising the humanity of others and on that basis establish human relations with them'.

However, Dladla (2017:56) argues that philosophically, Benezet Bujo explains umntu ngumntu ngabantu better than Ramose when Bujo argues that 'for Black Africa, it is not the Cartesian cogito ergo sum but an existential cognatus sum, ergo sumus (I am related; therefore, we are)'. Therefore, from this definition, Dladla (2017) argues that the obligation to be humane towards others is an ethical imperative based on the principle that one ought always to promote life and avoid killing:

$[U]$ buntu as ethics is insuperably connected to the recognition that motion is the principle of be-ing. Thus, the ethics of Ubuntu revolves around contingency and mutability. (p. 56)

Concurring with Bujo that 'there is no ethics as such, but only different ethical systems with identical ideas', Dladla (2017) argues that the ethical ideals are not always identical; Ubuntu is both the source and the embodiment of the ethics of the Bantu-speaking people. He argues that being human is not passively given:

[S]imple being born of the Homo sapiens may be a necessary condition to be human being but it is not sufficient. One ought to become -in the ethical sense-a human being. Dladla argues that in the philosophy of Ubuntu is indispensable complement to the ontological condition of being a human being. (Dladla 2017:51)

Therefore, Dladla argues the be-ing of oneself is always dependent on one's doing in relation to others and that is the recognition of their humanity and the establishment of humane relationships with them. He argues that everything from Bantu language, law and politics has no meaning if there are not others (abanye abantu) in its description, definition and practice.

Dladla points out that according to Ramose what is critical is 'to prove oneself to be the embodiment of ubu-ntu because the fundamental ethical, social and legal judgement of human worth and conduct is based upon Ubuntu'. Following the latter definition, therefore, Dladla (2017) argues that:

$[T]$ he determination whether one is uMuntu or not has its basis on the known history of the actions of a particular person and whether such as person has in fact conducted herself humanely. (p. 54)

and that is Ubuntu. Furthermore, he argues that this definition is also extended to a group of people if history of 
interactions is recorded between a given Bantu-speaking community and other groups.

For example, he argues that because of the historical interactions between white people and black people, white people are believed as not embodying Ubuntu. He argues that from the conquering of black people in the unjust wars of colonisation, the ethical judgement is made towards white people as not embodiments of Ubuntu (Dladla 2017:54). Dladla (2017:55) argues that this ethical judgement is based on the experience of the injustice in the form of:

- the so-called right of conquest, being the ethically unjustified usurpation of sovereign title to territory from abantu to abelungu

- political subjugation in the service of sustained systemic and systematic economic exploitation and

- racism to consolidate political subjugation and reinforce systemic and systematic economic exploitation.

Dladla argues that if a white person changes history and contradicts the negative history, then that it will be said by the Bantu that white people have Ubuntu. Therefore, to have Ubuntu is not a biological valuation but an ethical one (Dladla 2017).

\section{African Spirituality-Religiosity}

Relation of the individual to the family, the clan and the tribe in terms of politics, ethics, war, status, social amenities, festivals, all that is good and much that is bad in Bantu life is grounded in Bantu religion. (Ramose 2009:56)

Ramose (2009) argues that if we want to understand African religions, we must realise that Bantu life is significantly religious because the spirituality permeates the life of the people. The spirituality regulates their doings and governs their leisure to the extent that it is hard for those outside this spirituality to imagine. Steve Biko, the father of BTL in South Africa, once lamented the destruction of the Bantu ways of life and their epistemologies. He argued that Africans do not recognise any conceptual cleavage between the natural and supernatural. Biko (1978:45) explains that Africans do not believe that religion must feature as a separate part of our existence on earth; Spirituality manifests itself in African's daily life. Biko argues that Africans thanked God through their ancestors before they drank beer, married and worked. 'God was always in communication with us and therefore merited attention everywhere and anywhere' (Biko 1978:45). The political organisation in African society intertwined with traditional religions that even everyday life revolves around the meaning and role that the indigenous Africans ascribe to the living dead or the spirits.

Although African ethics God centredness dimensions have not yet been sufficiently considered, Benezet Bujo argues that African ethics are primarily anthropocentric. However, the human centredness of African ethics is fundamentally founded on the community model that includes the living and the living dead.
Bujo argues that to engage the African ethical community is not restricted to the living community, the invisible world of the ancestor's forms part of the society. The unseen world of the living dead plays a significant role in shaping morality within the community. So, therefore, in the aftermath of life on earth, the ancestors are responsible for their offspring remaining brave and resilient and thus, they are to set up moral directives for the welfare of their children. These directives must reflect the ancestor's experiences, thus giving wisdom and life. So, whoever does not live to follow ancestral ethics chooses death; however, to live according to them, that person opts flourishment and well-being for his/her life, the clan and the invisible and visible world dimensions (Bujo 2009).

Bujo (2009:116) argues that the individual and the community are not in conflict with one another as many believe, but they complement each other. Bujo explains that name giving on its own signals the value of the individual. He argues that name giving is not about the father's named being passed on to the next generation only, but it is about according to the circumstances of her/his own birth. The name that a child is given is never without particular individual meaning; it always expresses something of persons' being. 'It characterises the personal ontological reality'.

However, Bujo further argues that no person can embody and achieve the ethical idea individually or by personal achievement. In agreement with Bujo, Ramose (2009:56) reasons that the African tradition defines personhood in terms of wholeness, thus making the concept of being not a denial of human individuality an ontological fact. However, the African idea of a person as wholeness ascribes ontological primacy to the community through which the individual comes to know both himself and the world around him.

Ramose argues that this is why the human being in African thought is not definable in terms of the single physical or psychological characteristic with the exclusion of everything else. He argues that human being is defined by reference to the environing community because African understanding is that the reality of the communal world takes precedence over the reality of the individual life histories, whatever they might be'. The latter is meant to apply ontologically and must be accessible epistemologically.

I want to refer back to the argument that African religions are anthropocentric than theocentric. Indeed, I agree that it is true that the God-centredness of African ethics has not been explored in detail. However, I also want to argue that through African folktales, and storytelling, we do know that God in African traditions tends to be not monotheistic, but polytheistic. Moreover, the new generation of activists and scholars in Africa takes pride in the idea that African religions are polytheistic.

Bibi Bakare-Yusuf (2015:9) argues that the African spiritual tradition is polytheistic because it encompasses individual gods who function to serve different spiritual needs in society. Bakare-Yusuf (2015:9) demonstrates that a person's spiritual 
needs in polytheism changes across time and so is their theological allegiances. However, she also points out that this does not mean the gods change or anything. However, it means that polytheistic societies can live with different moral truth claims and negotiate the tensions that arise from similarity and difference without the exclusion of one for the other. This argument I think explains why African societies are not just made up of the individual living society but also the living dead. The plural arrangement of the community between the living dead and the living community can be characterised as the reflection from understanding religion as polytheistic. African gods do not compete with each other for the human or seek to colonise other gods in African societies, but they live in community with one another.

Therefore, my argument is that if we observe the Godcentredness African ethics, we will still arrive at the communal. It seems that even the gods are collective because Africans do not give allegiance to one God, the power of the gods is shared amongst each other and African folktales reflect this sharing of power. It makes that African ethics are not restricted to the living community; the invisible world of the ancestors forms part of the society and even the future generation is essential formation for an ethical society. Otherwise, how do we make sense of African proverbs that argue that "Take care of the earth, not because it was handed down to you by your grandparents, but because it was lent to you by your great-grandchildren'.

Moreover, scrutinising Africa as polytheistic, it can help us to understand how the AICs can be both Christian and its praxis, be that of African spirituality. Of course, I make this argument based on Bakare-Yusuf's statement that although Nigerian society in a colonial world is occupied by Christian and Islamic faith, the deep structure remains polytheistic. The structure is ordered by the spirit world of traditional gods, and it is revealed through aesthetic practices such as dance and music that polytheism in spirit translates into aesthetics of polyrhythm (Bakare-Yusuf 2015).

Considering the above-mentioned debate perhaps then, Vellem is right to argue that African religiosity is expressed in AICs and therefore, they are a site of the spirituality of liberation, which includes Ubuntu ethics/philosophy.

\section{African indigenous churches embodying African spirituality}

According to Vuyani Vellem, the third model of church is the 'struggle church' or struggle church established by Africans 'as a response to the defects encountered in both settler and missionary church models'. He gives an example of the Ethiopian church that is even older than the protestant churches (Vellem 2015). Within the context of South Africa, the struggle or resistance churches are the AICs that were initiated by Africans.

Vellem argues that the resistance church has been helpful within black resistance because, in its nature, it is an ecclesiology that speaks to the condition of black Africans.
Vellem (2015:2) argues that the spirituality found in AICs, in its essence, is subversive in the light of the dominant paradigms of ecclesiology in the settler and missionary models. It is founded on African culture, values and experiences. Vellem argues that African spirituality in AICs has 'maintained the sanity of the African soul within the underbelly of modernity'. He argues that the AICs are an expression of spirituality of sanity in the context of political, economic, spatial and cultural domination of a salvationist religion of the west that is experienced as terror by black people.

To illustrate this, Vellem uses Nontetha Nkwenkwe who established one of the very first AICs in South Africa. Nontetha is one of the remarkable examples of African religious leaders, a black woman, a seer, and a prophetess within the context of struggle church model. Vellem argues that Nontetha promoted unity amongst amaqaba (the unconverted black people) and amaqgobhoka (the converted black people). Nontetha preached unity amongst Africans and colonial administrators saw this as a problem because colonial regimes benefited from the divisions of Africans. Seemingly, it was the settler and the missionary church leaders and administrators who called the state administrators to see that Nontetha and her church destroyed as they complained that Nentetha was taking away their members and more importantly was practising African spirituality.

Nontetha in her church preached using African values and norms of salvation rooted in African Spirituality. The colonial authorities then incarcerated Nontetha for resisting to submit to the spiritual and psychic-cultural dominance of the west. Nontetha was incarcerated later on and admitted to Fort Beaufort mental hospital in 1924 and later to Weskoppies mental hospital in Pretoria. Nontetha was incarcerated and later admitted to a mental hospital because to embody African essence in colonised Azania is to commit suicide, as is madness.

Critiquing AICs, Vellem admits that ideologised religion under the black government, even in the context of the resistance church, has become a danger for the very foundation of resistance church in South Africa. Although these churches might have lost the reasons why they broke off from the colonial settler churches and are lacking blackness as an interlocutor in democratic South Africa, Vellem believes that instead of BTL always asserting itself in these new white theologies, and settler, missionary models of church, discussed here, BTL needs to focus on a spirituality of liberation that is in conversation with African religiosity found in the AICs (Vellem 2015).

In this space, I want to posit that within the context of Christianity in Africa, the AICs are where we can hope for the spirituality of liberation that originates in African culture. Ubuntu, in my view and within the context of AICs, can be reconceptualised as a conscious spirituality of revolution, thus utilising AICs as prototypes for the movement towards African spirituality of Ubuntu. As the new generation we must avoid repeating old debates about the need of African 
spirituality and culture or a revolutionary culture because the revolutionary culture is not working under a black government. Therefore, in my view, the new generation of black liberation theologians and youth in the church has two choices to think about to unthink the west. First is to ponder whether to move to African spirituality and expel Jesus Christ is feasible in a time that people are so duped in Christianity that they eat grass if the church and the priests tell them to. The second choice is to advance the African spirituality of Ubuntu and culture found in the AICs through BLT liberative paradigms. The other choice is that one of Xola Skosana that 'Christ cannot be Blackened' and thus, even BTL will not be able to help black people in South Africa. Although another question still arises, the question by Patrick Matabene, that if we expel Christ and embrace only African spirituality what if the ancestors prove equally to be impotent in the face of white spirituality of racism? ${ }^{4}$

Of course, Vuyani Vellem will advise the youth that we must be careful of any pondering of spirituality without conspiring the poor, because it will remain in the sky. Vellem (2014) will argue that we must avoid any dualities between spirituality and consciousness when we think about the black imagery and religiosity.

In conclusion, Vuyani Vellem (2017) will argue that for BTL, the subversive character of the AICs is the memory of the miserable, the condition of blackness. Therefore:

$[I] \mathrm{n}$ the context of breathlessness, the rising spirit of black person in decolonial times is the spirit to reject the finality of the West, conceptual assumptions that hobbled and blinded contemporary thought politics. (p. 8)

\section{Acknowledgements Competing interests}

The author declares that she has no financial or personal relationship(s), which may have inappropriately influenced her in writing this article.

\section{Author's contributions}

I declare that I am the sole author of this research article.

\section{Ethical consideration}

The author confirms that ethical clearance was not needed for this study.

4.https://www.youtube.com/watch?v=7wcxpujgilwy

\section{Funding information}

This research received no specific grant from any funding agency in the public, commercial, or not-for-profit sectors.

\section{Data availability statement}

Data sharing is not applicable to this article as no new data were created or analysed in this study.

\section{Disclaimer}

The views and opinions expressed in this article are those of the authors and do not necessarily reflect the official policy or position of any affiliated agency of the authors.

\section{References}

Bakare-Yusuf, B., 2015, “'Yoruba's don't do gender": A critical review of Oyeronke Oyewumi's the invention of women: Making an African sense of western gender discourses by', African Identities 1, 121-43.

Biko, S., 1978, I write what I like: Selected writings, in A. Stubbs (ed.), pp. 1-153, University of Chicago Press, Chicago, IL.

Boesak, A., 2017, Pharaohs on Both sides of the Blood red -waters: Prophetic critique of Empire: Resistance, Justice, and the Power of the Hopeful Sizwe-A Transatlantic Conversation, Wpf \& Stock Publishers, Eugene, Oregon.

Booysen, S., 2016, Fees Must Fall: Student revolt, decolonisation and governance in South Africa, Wits University Press, Johannesburg.

Bujo, B., 2009, 'Is There a Specific Ethic? Towards a Discussion with Western Thought', in M.F. Murove (ed.), African Ethics: An Anthology of Comparative and Applied Ethics, University of Kwazulu-Natal Press, Scottsville.

Chigumadzi, P., 2015, Of coconuts, consciousness and Cecil John Rhodes: Disillusionment and disavowals of the Rainbow Nation, viewed 30 May 2017, from http://www.journalism.co.za/wp-content/uploads/2015/08/Ruth-FirstFINALDraft-_Panashe-Chigumadzi.pdf .

Dladla, N., 2017, 'Towards an African critical philosophy of race: Ubuntu as a philopraxis of liberation', Filosofia Theoretica: Journal of African Philosophy, Culture and Religions 6(1), 39-68. https://doi.org/10.4314/ft.v6i1.3

Dussel, E.N. \& Ibarra-Colado, E., 2006, 'Globalization, Organization and the ethics of liberation', Organisation 13(4), 489-508. https://doi.org/10.1177/ 1350508406065852

Ngcamu, B.S. \& Mantzaris, E., 2019, 'Xenophobic violence and criminality in the KwaZulu-Natal townships: Research', The Journal for Transdisciplinary Research in Southern Africa 15(1), 1-8. https://doi.org/10.4102/td.v15i1.606

Ramose, M.B., 2009, African philosophy through Ubuntu, Mond Books, Harare.

Rotblat, J. (ed.), 2001, Proceedings of the forty-ninth Pugwash conference on science and world affairs: Rustenburg, South Africa, 7-13 September 1999: Confronting the challenges of the 21st century, World Scientific, River Edge, NJ.

Tutu, D., 1999, No future without forgiveness, Nachdr, An Image Book, Doubleday, New York, NY

Vellem, V.S., 2012, 'Interlocution and black theology of liberation in the 21st century: A reflection', Studia Historiae Ecclesiasticae 38, 345-360.

Vellem, V.S., 2014, 'Spirituality of liberation: A conversation with African religiosity', HTS Teologiese Studies/Theological Studies 70(1), 1-7. https://doi.org/10.4102/ hts.v70i1.2752

Vellem, V.S., 2015, 'Unshackling the church', HTS Teologiese Studies/Theological Studies 71(3), 5. https://doi.org/10.4102/hts.v71i3.3119

Vellem, V.S., 2017, 'Un-thinking the West: The spirit of doing Black Theology of Liberation in decolonial times', HTS Teologiese Studies/Theological Studies 73(3), 1-9. https://doi.org/10.4102/hts.v73i3.4737 